\title{
Effects of Iridoids on Lipoxygenase and Hyaluronidase Activities and Their Activation by $\beta$-Glucosidase in the Presence of Amino Acids
}

\author{
Sui-Kiong Ling, Takashi Tanaka, and Isao Kouno* \\ Course of Pharmaceutical Sciences, Graduate School of Biomedical Sciences, Nagasaki University; 1-14 Bunkyo-machi, \\ Nagasaki 852-8521, Japan. \\ Received September 26, 2002; accepted December 26, 2002; published online December 27, 2002
}

\begin{abstract}
Enzyme inhibitory activities of 14 iridoids previously obtained from two Malaysian medicinal plants, Saprosma scortechinii and Rothmannia macrophylla, were evaluated in vitro using soybean lipoxygenase and bovine testis hyaluronidase. Most of the iridoids, including asperulosidic acid, paederosidic acid, and an epimeric mixture of gardenogenins $A$ and $B$, did not show any effect on the enzyme activities, except for the bis-iridoids, which inhibited the lipoxygenase activity with their $\mathrm{IC}_{50}$ values of approximately 1.3 times that of a known inhibitor, fisetin. Structural modification of asperulosidic acid and paederosidic acid through enzymatic hydrolysis by $\beta$-glucosidase resulted in their inhibition towards the enzyme activities, and these activities were enhanced by the presence of some amino acids (lysine, leucine or glutamic acid) or ammonium acetate. Mixtures of gardenogenins $A$ and $B$; isomers of non-glucosidic iridoids, incubated with amino acid or ammonium acetate did not show any inhibitory effect on the enzyme activities during the $6 \mathrm{~h}$ incubation period, except for lysine where spontaneous reaction between the iridoids and amino acid resulted in the inhibition of lipoxygenase activity. The results from these biomimetic reactions suggested that the iridoid aglycons and the intermediates formed by these reactive species could inhibit the enzyme activities, and thus substantiate previous reports that the formation of iridoidal aglycons is a prerequisite for the iridoid glycosides to demonstrate some of the biological activities. In addition, the results also indicated that it is worthwhile to further explore these intermediates as potential anti-inflammatory agents.
\end{abstract}

Key words iridoid glucoside; lipoxygenase inhibition; hyaluronidase inhibition; $\beta$-glucosidase; amino acid

Iridoid glycosides represent a large group of cyclopentano $[c]$ pyran monoterpenoids which are known to be associated with diverse biological activities including choleretic, purgative, liver protective, vasoconstrictive, antimicrobial, analgesic, antitumor, sedative and anti-inflammatory activities. ${ }^{1,2)}$ Nevertheless, the chemical bases that lie under these interesting characteristics of iridoids have not yet been well explained. Generally, iridoid glycosides are unstable to acid and $\beta$-glucosidases, ${ }^{2}$ generating the corresponding hemiacetal, which is in equilibrium with the dialdehyde (Chart 1). Other reactions can generate a number of possible intermediates, such as Schiff bases resulting from reaction with the amino groups of proteins, while the presence of functional groups on the cyclopentane ring may increase the number of intermediates that can be formed. ${ }^{2)}$ All these changes are influenced by the $\mathrm{pH}$ of the medium.

Lipoxygenases (EC 1.13.11.12) are widely distributed in plants and animals, which catalyze the incorporation of dioxygen molecules into polyunsaturated fatty acid containing one or several cis,cis-pentadiene systems, and leads to the formation of hydroperoxides. ${ }^{3,4)}$ In mammals, three major types of lipoxygenases have been identified, inserting dioxygen at $\mathrm{C}-5, \mathrm{C}-12$ and $\mathrm{C}-15$ positions of arachidonic acid, respectively. ${ }^{5}$ Due to the proposed role of lipoxygenase-derived metabolites (leukotriences and lipoxines) in a number of pathophysiological processes such as asthma, psoriasis, cancer metastasis and atherosclerosis, ${ }^{6-8)}$ there is a considerable interest in searching for compounds that can prevent the formation of these mediators through the lipoxygenase pathway in the arachidonate cascade. ${ }^{9)}$

On the other hand, hyaluronidases (EC 3.2.1.35) are enzymes capable of hydrolyzing hyaluronic acid, one of the most abundant constituents of the extracellular matrix, which

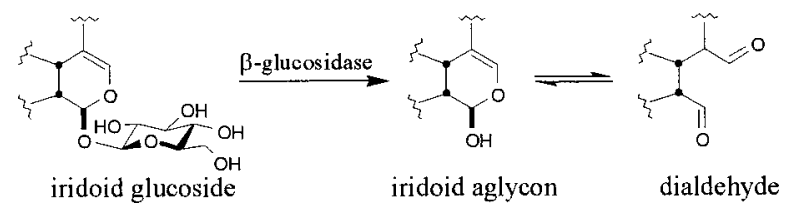

Chart 1. Proposed Hydrolysis Products of Iridoid Glucoside

is ubiquitously distributed in body tissues. ${ }^{10)}$ These enzymes have been implicated to many biological functions, including allergy, ${ }^{11)}$ inflammation, ${ }^{12-16)}$ migration of cancer cells, ${ }^{17)}$ and permeability of the vascular system. ${ }^{18)}$ Therefore, the modulation of hyaluronidases by suitable inhibitors will be useful for normal homeostasis in the body.

As part of a study on Malaysian medicinal plants, we examined the effects of 14 iridoids (saprosmosides A, D, E and $\mathrm{G}$, asperulosidic acid, paederosidic acid, 6-epi-paederosidic acid, methylpaederosidate, $6 \alpha$-hydroxygeniposide, asperuloside, paederoside, macrophylloside, gardenogenins A and B) previously isolated from Saprosma scortechinii, ${ }^{19,20)}$ and Rothmannia macrophylla $a^{21)}$ on the in vitro lipoxygenase and hyaluronidase activities. These plants have been employed in the traditional medicinal system to treat fever, and as a contraceptive agent, respectively. In the present study, the possible involvement of iridoid aglycons in the enzyme inhibition and the activation by the presence of nitrogenous compounds were evaluated, while the chemical bases underlying these biomimetic reactions are also discussed.

\section{MATERIALS AND METHODS}

Chemicals and General Materials The iridoid glucosides were isolated from the methanol extracts of Saprosma 

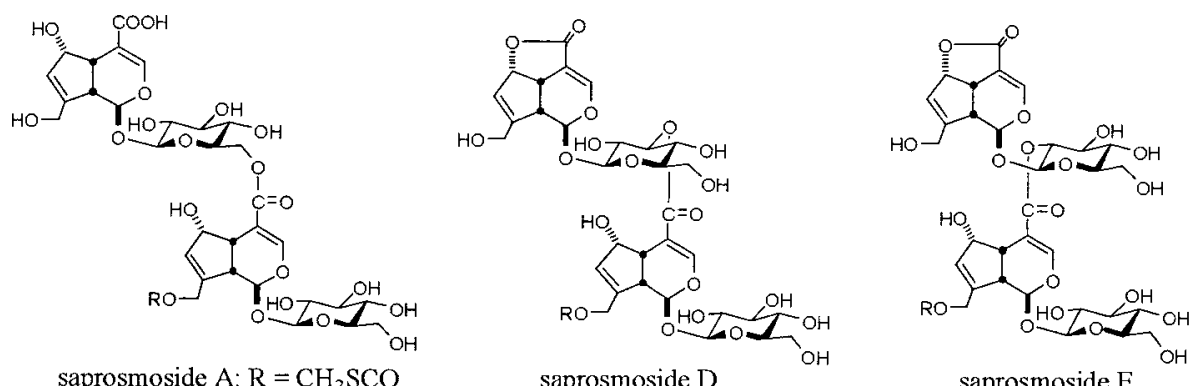
saprosmoside $\mathrm{G}: \mathrm{R}=\mathrm{H}$
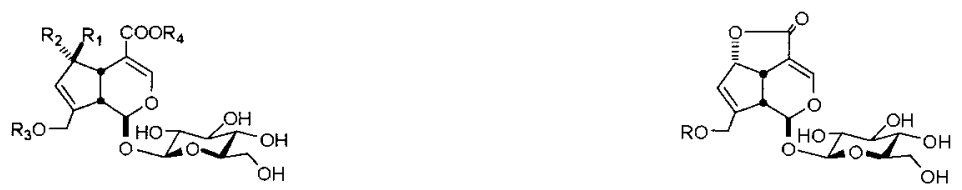

asperulosidic acid: $\mathrm{R}_{1}, \mathrm{R}_{4}=\mathrm{H} ; \mathrm{R}_{2}=\mathrm{OH} ; \mathrm{R}_{3}=\mathrm{CH}_{3} \mathrm{CO}$ paederosidic acid: $\mathrm{R}_{1}, \mathrm{R}_{4}=\mathrm{H} ; \mathrm{R}_{2}=\mathrm{OH} ; \mathrm{R}_{3}=\mathrm{CH}_{3} \mathrm{SCO}$ 6-epi-paederosidic acid: $\mathrm{R}_{1}=\mathrm{OH} ; \mathrm{R}_{2}, \mathrm{R}_{4}=\mathrm{H} ; \mathrm{R}_{3}=\mathrm{CH}_{3} \mathrm{SCO}$ methylpaederosidate: $\mathrm{R}_{1}=\mathrm{H} ; \mathrm{R}_{2}=\mathrm{OH} ; \mathrm{R}_{3}=\mathrm{CH}_{3} \mathrm{SCO} ; \mathrm{R}_{4}=\mathrm{CH}_{3}$ $6 \alpha$-hydroxygeniposide: $\mathrm{R}_{1}=\mathrm{H} ; \mathrm{R}_{2}, \mathrm{R}_{3}=\mathrm{OH} ; \mathrm{R}_{4}=\mathrm{CH}_{3}$

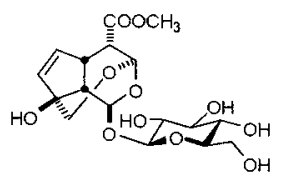

macrophylloside

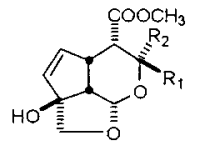

gardenogenin $\mathrm{A}: \mathrm{R}_{1}=\mathrm{H}, \mathrm{R}_{2}=\mathrm{OH}$ gardenogenin $B: R_{1}=O H ; R_{2}=H$ asperuloside: $\mathrm{R}=\mathrm{CH}_{3} \mathrm{CO}$ paederoside: $\mathrm{R}=\mathrm{CH}_{3} \mathrm{SCO}$

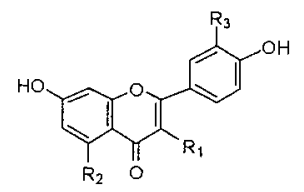

fisetin: $\mathrm{R}_{1}, \mathrm{R}_{3}=\mathrm{OH} ; \mathrm{R}_{2}=\mathrm{H}$ apigenin: $\mathrm{R}_{1}, \mathrm{R}_{3}=\mathrm{H} ; \mathrm{R}_{2}=\mathrm{OH}$

Chart 2. Chemical Structures of Iridoid Glucosides and Reference Compounds

scortechinii and Rothmannia macrophylla as described previously $^{19-21)}$ (Chart 2). Lipoxygenase (soybean, type 1-B), linoleic acid, hyaluronidase (bovine testes, type 1-S), hyaluronic acid (human umbilical cord, sodium salt), bovine serum albumin, and ammonium acetate were purchased from Sigma Chemical Co. Almond $\beta$-glucosidase, boric acid, fisetin, L-lysine, L-leucine, and L-glutamic acid were purchased from Wako Chemical Co. Apigenin was obtained through acid hydrolysis of apiin, which was isolated from parsley.

Lipoxygenase Assay This assay was performed according to the procedure described by Sigma, with slight modifications. Enzyme activity was measured spectrophotometrically using a JASCO UV-VIS spectrophotometer, in borate buffer $(0.2 \mathrm{M}, \mathrm{pH} 9.0)$ by the increase in absorbance at $234 \mathrm{~nm}, 25^{\circ} \mathrm{C}$, between 90 and $210 \mathrm{~s}$ after addition of lipoxygenase $(167 \mathrm{U} / \mathrm{ml}$, final concentration), using linoleic acid $(134 \mu \mathrm{M})$ as substrate. The enzyme solution was kept in ice, and controls (100\% enzyme activity) were measured before the test samples. For the test, the enzyme solution was preincubated with the test sample for $5 \mathrm{~min}$ at $25^{\circ} \mathrm{C}$, followed by addition of substrate solution and borate buffer to the final volume of $1.5 \mathrm{ml}$. The enzyme activity was calculated as the rate of change of absorbance per unit time. The enzyme inhibitory activity was expressed as the percentage ratio of the difference in enzyme activity between the test sample and control vs. enzyme activity in the control experiment. Samples were tested at maximum concentration of $200 \mu \mathrm{M}$ in the final volume of assay mixture. The concentration reducing enzyme activity by $50 \%$ with respect to the control was esti- mated from graphic plots of a concentration dependent study and was defined as $\mathrm{IC}_{50}$ expressed in $\mu \mathrm{M}$. The values were presented as mean \pm S.D. of at least two or three determinations in duplicates. Fisetin was employed as positive control and added as dimethyl sulfoxide (DMSO) solution.

Hyaluronidase Assay The assay was performed according to the Sigma protocol with slight modifications. The assay medium consisting of $1.00-1.67 \mathrm{U}$ hyaluronidase in $100 \mu 120 \mathrm{~mm}$ sodium phosphate buffer $\mathrm{pH} 7.0$ with $77 \mathrm{~mm}$ sodium chloride and $0.01 \%$ BSA was preincubated with $5 \mu \mathrm{l}$ of the test compound (in DMSO) for $10 \mathrm{~min}$ at $37^{\circ} \mathrm{C}$. Then the assay was commenced by adding $100 \mu \mathrm{l}$ hyaluronic acid $(0.03 \%$ in $300 \mathrm{~mm}$ sodium phosphate, $\mathrm{pH} 5.35)$ to the incubation mixture and incubated for a further $45 \mathrm{~min}$ at $37^{\circ} \mathrm{C}$. The undigested hyaluronic acid was precipitated with $1 \mathrm{ml}$ acid albumin solution made up of $0.1 \%$ bovine serum albumin in $24 \mathrm{~mm}$ sodium acetate and $79 \mathrm{~mm}$ acetic acid, $\mathrm{pH} 3.75$. After standing at room temperature for $10 \mathrm{~min}$, the absorbance of the reaction mixture was measured at $600 \mathrm{~nm}$. The absorbance in the absence of enzyme was used as the reference value for maximum inhibition. The inhibitory activity of test compound was calculated as the percentage ratio of the absorbance in the presence of test compound $v s$. absorbance in the absence of enzyme. The enzyme activity was checked by control experiment run simultaneously, in which the enzyme was preincubated with $5 \mu \mathrm{l}$ DMSO instead, and followed by the assay procedures described above. In this case, the percentage ratio of the absorbance in the presence of enzyme $v s$. that in the absence of enzyme was in the range of $15-20 \%$. The performance of the assay was verified using apigenin as 
a reference under exactly the same experimental conditions. Compounds were tested at a maximum concentration of $50 \times 10^{2} \mu \mathrm{M}$ in the final reaction mixture. The results were expressed as mean of the $\mathrm{IC}_{50}$ values \pm S.D. of three separate experiments measured in triplicates.

Activation of Iridoids towards the Inhibitory Activities on Lipoxygenase and Hyaluronidase with the Presence of $\boldsymbol{\beta}$-Glucosidase, Amino Acids or Ammonium Acetate Asperulosidic acid or paederosidic acid was dissolved in $0.1 \mathrm{M}$ sodium acetate buffer, $\mathrm{pH} 5.0$, or $0.1 \mathrm{M}$ sodium phosphate buffer, pH $7.0 \quad(20 \mathrm{mg} / \mathrm{ml}) \quad$ containing $\beta$-glucosidase $(2 \mathrm{mg} / \mathrm{ml})$, or amino acid $(10 \mathrm{mg} / \mathrm{ml})$, or both, or in $10 \% \mathrm{am}-$ monium acetate solution $(20 \mathrm{mg} / \mathrm{ml})$ containing $\beta$-glucosidase $(2 \mathrm{mg} / \mathrm{ml})$, and incubated at $37^{\circ} \mathrm{C}$ for $6 \mathrm{~h}$. On the other hand, mixture of gardenogenins $\mathrm{A}$ and $\mathrm{B}$ was dissolved in the buffer containing amino acid, or in $10 \%$ ammonium acetate solution, and incubated under similar experimental conditions described above. At intervals, $5 \mu$ l from each incubation mixture was tested for the effect on lipoxygenase or hyaluronidase activity using the assays described above, and the results were presented as mean of the percentage inhibitory activities \pm S.D. of two or three determinations in duplicates for the former, and mean \pm S.D. of three independent experiments performed in triplicates for the later. The concentrations of asperulosidic acid, paederosidic acid and mixture of gardenogenins $\mathrm{A}$ and $\mathrm{B}$ in the final volume of assay mixture were calculated as $167.0,144.0$ and $275.0 \mu \mathrm{M}$ for lipoxygenase assay, and 12.2, 10.5 and $20.2\left(\times 10^{2}\right) \mu \mathrm{M}$ for hyaluronidase assay, respectively.

\section{RESULTS AND DISCUSSION}

Previous studies on the leaves of Rothmannia macrophylla, and the leaves and stems of Saprosma scortechinii have resulted in the isolation of a total of 37 iridoids. ${ }^{19-21)}$ In this study, we examined the enzyme inhibitory activities of 14 available iridoids using two in vitro assay systems with lipoxygenase and hyaluronidase. Most of the iridoids did not show any inhibitory activity, except for the bis-iridoids; saprosmosides A, D, E, and G, which inhibited lipoxygenase activity with their $\mathrm{IC}_{50}$ values of $164.0,157.2,174.5$ and $154.2 \mu \mathrm{M}$, respectively (Table 1 ). However, these $\mathrm{IC}_{50}$ values were higher than those of the known lipoxygenase inhibitor, fisetin (Table 1). In contrast, all the iridoids tested did not show any hyaluronidase inhibitory activity at concentrations up till $5 \mathrm{~mm}$.

It is believed that the biological activities of iridoids are attributable to their aglycons, which readily transform into reactive intermediates in the presence of $\beta$-glucosidase or acid. $^{2)}$ There were a few reports where iridoids with a glucosidic or acetal ester linkage at C-1 are less active than the corresponding compounds with a free hydroxyl at $\left.\mathrm{C}-1 .{ }^{2}\right) \mathrm{De}-$ spite such reports on activities such as antitumor, ${ }^{22,23)}$ antimicrobial, $^{24)}$ and antiviral, ${ }^{25,26)}$ there was no report on the effects of these intermediate species on the lipoxygenase and hyaluronidase activities. This prompted us to conduct the second part of this study to investigate whether asperulosidic acid, paederosidic acid and mixture of gardenogenins $\mathrm{A}$ and $B$ could inhibit these enzyme activities after hydrolysis with $\beta$-glucosidase or in the presence of a nitrogenous compound. For this purpose, the iridoid glucosides asperulosidic acid
Table 1. Lipoxygenase (Lox) and Hyaluronidase (Hya) Inhibitory Activities of Iridoids

\begin{tabular}{lcc}
\hline \hline \multirow{2}{*}{ Compounds } & \multicolumn{2}{c}{$\mathrm{IC}_{50}(\mu \mathrm{M})$} \\
\cline { 2 - 3 } & $\mathrm{Lox}^{b)}$ & $\mathrm{Hya}^{c)}$ \\
\hline Saprosmoside A & $164.0 \pm 2.8$ & $\mathrm{NA}$ \\
Saprosmoside D & $157.2 \pm 4.5$ & $\mathrm{NA}$ \\
Saprosmoside E & $174.5 \pm 6.7$ & $\mathrm{NA}$ \\
Saprosmoside G & $154.2 \pm 1.8$ & $\mathrm{NA}$ \\
Asperulosidic acid & $\mathrm{NA}$ & $\mathrm{NA}$ \\
Paederosidic acid & $\mathrm{NA}$ & $\mathrm{NA}$ \\
6-epi-Paederosidic acid & $\mathrm{NA}$ & $\mathrm{NA}$ \\
Methylpaederosidate & $>200$ & $\mathrm{NA}$ \\
6 $\alpha$-Hydroxygeniposide & $>200$ & $\mathrm{NA}$ \\
Asperuloside & $\mathrm{NA}$ & $\mathrm{NA}$ \\
Paederoside & $\mathrm{NA}$ & $\mathrm{NA}$ \\
Macrophylloside & $\mathrm{NA}$ & $\mathrm{NA}$ \\
Gardenogenins A and B & $\mathrm{NA}$ & $\mathrm{NA}$ \\
Fisetin $^{a)}$ & $124.0 \pm 8.0$ & - \\
Apigenin & - & $510 \pm 20$ \\
\hline
\end{tabular}

NA, Inhibitory activity $<20 \%$ at concentrations up to $200 \mu_{\mathrm{M}}$ (Lox), and $5 \times 10^{3} \mu_{\mathrm{M}}$ (Hya). a) Positive control. b) Values were presented as the mean \pm S.D. of two or three independent experiments performed in duplicates. c) Values were presented as the mean \pm S.D. of three independent experiments performed in triplicates.

and paederosidic acid were structurally modified by enzymatic hydrolysis of $\beta$-glucosidase and with the presence of a nitrogenous compound (L-lysine, L-leucine, L-glutamic acid or ammonium acetate). In the case of the non-glucosidic iridoid, structural modification of the epimers, gardenogenins A and $\mathrm{B}$ was achieved by direct incubation with the nitrogenous compound mentioned as above.

Asperulosidic acid and paederosidic acid were obtained as two of the major iridoid glucosides present in the leaves and stems of Saprosma scortechinii of the family Rubiaceae, ${ }^{19,20)}$ which has been employed to treat fever by the native communities in Malaysia. The latter contains an unusual $S$-methylcarbonate function, which is easily hydrolyzed by an enzyme released from bruised plant tissue, and is responsible for the unpleasant odor of methyl mercaptan. Similarly, gardenogenins A and B were the major non-glucosidic iridoids present in Rothmannia macrophylla, isolated as an inseparable epimeric mixture. ${ }^{21)}$ These four iridoids did not show any lipoxygenase or hyaluronidase inhibitory activity in their present forms (Table 1). However, mixtures containing asperulosidic acid or paederosidic acid preincubated with $\beta$-glucosidase, or $\beta$-glucosidase and amino acid or ammonium acetate exhibited lipoxygenase inhibitory activity (Fig. 1, I and II). The inhibitory activities were higher in the presence of certain nitrogenous compound than that of $\beta$-glucosidase alone. The presence of leucine was observed to cause a higher inhibitory effect of asperulosidic acid on the lipoxygenase activity. For paederosidic acid, higher lipoxygenase inhibition was observed with lysine, leucine or ammonium acetate. In the case of mixtures of gardenogenins A and B, lipoxygenase inhibition was shown only with the presence of lysine (Fig. 1, III). These results showed that the formation of hemiacetals together with presence of 3,4 unsaturation in the aglycons of the $\beta$-glucosidase treated asperulosidic acid or paederosidic acid were essential for demonstrating the enzyme inhibitory activities, since mixtures of gardenogenins $\mathrm{A}$ and $\mathrm{B}$, which also contained hemiacetal function but lacked of the double bond did not show any inhibitory activity. Additionally, the 

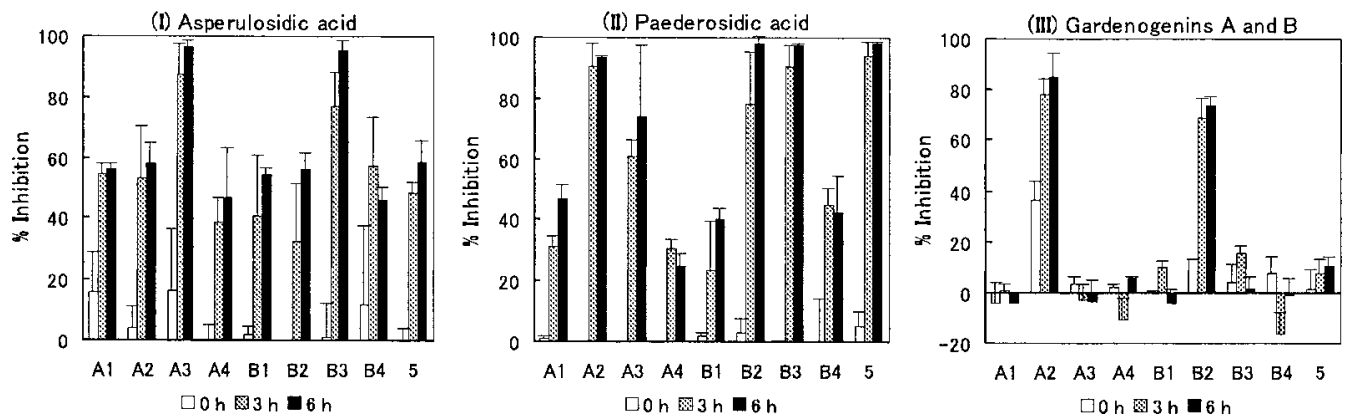

Fig. 1. Lipoxygenase Inhibitory Activity of Iridoids, (I) and (II) in the Presence of $\beta$-Glucosidase and a Nitrogenous Compound, and (III) in the Presence of a Nitrogenous Compound Alone at 0,3 and $6 \mathrm{~h}$ Intervals

(A) $\mathrm{pH} 5.0$; (B) pH 7.0; (1) buffer alone; (2) L-lysine; (3) L-leucine; (4) L-glutamic acid; (5) 10\% ammonium acetate. Bars represent mean \pm S.D. of two or three experiments performed in duplicates.
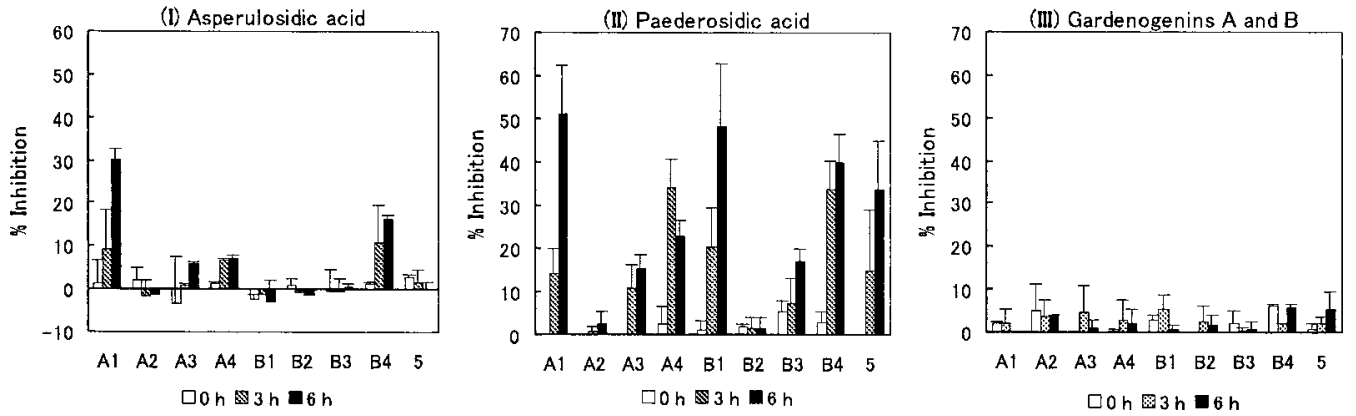

Fig. 2. Hyaluronidase Inhibitory Activity of Iridoids, (I) and (II) in the Presence of $\beta$-Glucosidase and a Nitrogenous Compound, and (III) in the Presence of a Nitrogenous Compound Alone at 0,3 and $6 \mathrm{~h}$ Intervals

(A) pH 5.0; (B) pH 7.0; (1) buffer alone; (2) L-lysine; (3) L-leucine; (4) L-glutamic acid; (5) 10\% ammonium acetate. Bars represent mean \pm S.D. of three experiments performed in triplicates.

hemiacetals of the iridoid aglycons can react with nitrogen donors to form intermediate species which are more potent as lipoxygenase inhibitors.

In terms of hyaluronidase inhibition, asperulosidic acid and paederosidic acid were shown to exhibit different inhibitory patterns as compared to that observed for lipoxygenase under similar experimental conditions (Fig. 2, I and II), while none of the mixtures of gardenogenins $\mathrm{A}$ and $\mathrm{B}$ showed hyaluronidase inhibitory activity above $10 \%$ (Fig. 2, III). Asperulosidic acid was shown to exhibit about $30 \%$ inhibitory activity only with the presence of $\beta$-glucosidase at $\mathrm{pH} 5.0$ during the $6 \mathrm{~h}$ incubation period. Paederosidic acid incubated with $\beta$-glucosidase alone at $\mathrm{pH} 5.0$ or 7.0 was shown to exhibit the highest inhibitory activity, followed by mixtures containing $\beta$-glucosidase and glutamic acid, $\beta$-glucosidase and $10 \%$ ammonium acetate, and $\beta$-glucosidase and leucine. Mixture containing $\beta$-glucosidase and lysine did not show any hyaluronidase inhibition in contrast to that observed for lipoxygenase inhibition. These results indicated that the formation of intermediate species between the nitrogen donors and the aglycons did not improve the hyaluronidase inhibitory activity of asperulosidic acid and paederosidic acid, when compared to their aglycons, which was contrasting to that observed for lipoxygenase inhibition. Therefore, some degrees of selective enzyme inhibition were shown by these intermediate species.

In terms of the $\mathrm{pH}$ of the medium, $\mathrm{pH} 7.0$ was able to maintain the enzyme inhibitory activity of the mixture, over a period of $24 \mathrm{~h}$ (data not shown). In the case of $\mathrm{pH} 5.0$, the en- zyme inhibitory activity decreased after $24 \mathrm{~h}$, which suggested that the bioactive species generated were more stable in the neutral than in the acidic condition. Iridoid glucosides incubated in the buffer alone, or with amino acid alone did not affect the enzyme activities (data not shown).

The mixture containing asperulosidic acid or paederosidic acid with $\beta$-glucosidase gradually changed color from yellow to brown, and finally a brown precipitate was formed after $6 \mathrm{~h}$ incubation, while those containing both $\beta$-glucosidase and lysine, leucine or glutamic acid, or ammonium acetate were observed to produce gradual darkening which progressed with prolong incubation to ultimately form different shades of deep blue coloration, not observed with the iridoid glucoside incubated alone. The mixture containing gardenogenins $\mathrm{A}$ and $\mathrm{B}$ incubated with lysine was observed to react spontaneously to give a purple coloration, while the reactions were slow in the presence of leucine, glutamic acid or ammonium acetate. This observation indicated that the rate of formation of intermediate species from the reaction between the iridoid aglycons and the nitrogen donors were different among L-lysine, L-leucine, L-glutamic acid and ammonium acetate, and this could play a crucial role in the enzyme inhibitory activities of the different reaction mixtures. The formation of pigments from reaction of certain iridoid aglycons with amino acids have been reported previously and were used as valuable food colorants or dyes. ${ }^{27-30)}$ Recently, blue pigments derived by condensation of glycine with genipin and mussaenoside showed anti-inflammatory and analgesic effects much stronger than that of the iridoidal 
compounds. $^{31)}$ Our results demonstrated that the pigments formed in the reaction mixtures may be responsible for the lipoxygenase and hyaluronidase inhibition.

As a conclusion, this is the first study to report on the inhibitory activities of asperulosidic acid, paederosidic acid and gardenogenins $\mathrm{A}$ and $\mathrm{B}$ on lipoxygenase and hyaluronidase through hydrolysis with $\beta$-glucosidase, or in the presence of amino acid or ammonium acetate. Whether the observed pattern of inhibition is representative of that occurring in vivo remains speculative, but the results do support the hypothesis that the biological activities of iridoid glucosides in vivo is partly attributable to their aglycons through a glutaraldehyde-like protein cross-linking mechanism. ${ }^{32-35)}$ The two subject species, Saprosma scortechinii and Rothmannia macrophylla contain iridoids as their major constituents. Therefore, the results of this study may indicate that some of these iridoids could play a role in the prevention against lipoxygenase or hyaluronidase mediated reactions in the body, through their hydrolysis products, or when these intermediates coexist with some nitrogenous compounds in the body. Further exploration on these iridoids may be useful and could lead to new paradigms of anti-inflammatory agents.

Acknowledgements The first author acknowledges the Forest Research Institute Malaysia for study leave, and the Ministry of Education, Science, Sports and Cultures of Japan for a scholarship.

\section{REFERENCES}

1) Sticher O., "New Natural Products and Plant Drugs with Pharmacological, Biological or Therapeutical Activity," ed. by Wagner H., Wolff P., Springer-Verlag, New York, Berlin, 1977.

2) Ghisalberti E. L., Phytomedicine, 5, 147-163 (1998).

3) Vliegenthart J. F. G., Veldink G. A., "Free Radicals in Biology," Vol. V, ed. by Pryor W. A., Academic, New York, 1982, pp. 29-64.

4) Papatheofanis F. J., Lands W. E. M., "Biochemistry of Arachidonic Acid Metabolism," ed. by Lands W. E. M., Martinus Nijhoff, Boston, 1985, pp. 9-39.

5) Smith W. L., Laneuville O., "Prostaglandin Inhibitors in Tumor Immunology and Immunotherapy," ed. by Harris J. E., Braun D. P., Anderson K. M., CRC Press, Inc., 1994, pp. 1-39.

6) Samuelsson B., Science, 220, 568-575 (1983).

7) Lewis R. A., Austen K. F., Soberman R. J., New England J. Med., 323, 645-655 (1990).
8) Henderson W. R., Ann. Intern. Med., 121, 684-697 (1994).

9) Gleason J. G., Perchonock C. D., Torphy T. J., Annu. Rep. Med. Chem., 21, 73-83 (1986).

10) Trochon V., Blot E., Cymbalista F., Engelmann C., Tang R.-P., Thomaidis A., Vasse M., Soria J., Lu H., Soria C., Int. J. Cancer, 85, 691-696 (2000).

11) Kakegawa H., Matsumoto H., Satoh T., Planta Medica, 54, 385-389 (1988).

12) Guerra F., Science, 103, 686-687 (1946).

13) Szary A., Kowalczyk-Bronisz S. H., Gieldanowski J., Arch. Immunol. Ther. Exp. Warsz., 23, 131-134 (1975).

14) Feinberg R. N., Beebe D. C., Science, 220, 1177-1179 (1983).

15) West D. C., Kumar S., Exp. Cell Res., 183, 179-196 (1989).

16) Horton M. R., Mckee C. M., Bao C., Liao F., Farber J. M., Hodge-DuFour J., Purae E., Oliver B. L., Wright T. M., Noble P. W., J. Biol. Chem., 273, 35088-35094 (1998).

17) Cameron E., Pauling L., Leibovitz B., Cancer Res., 39, 663-681 (1979).

18) Meyer K., Physiol. Rev., 27, 335-359 (1947).

19) Ling S.-K., Komorita A., Tanaka T., Fujioka T., Mihashi K., Kouno I., J. Nat. Prod., 65, 656-660 (2002).

20) Ling S.-K., Komorita A., Tanaka T., Fujioka T., Mihashi K., Kouno I., Chem. Pharm. Bull., 50, 1035-1040 (2002).

21) Ling S.-K., Tanaka T., Kouno I., J. Nat. Prod., 64, 796-798 (2001).

22) Ishiguro K., Yamaki M., Takagi S., Ikeda Y., Kawakami K., Ito K., Nose T., Chem. Pharm. Bull., 34, 2375-2379 (1986).

23) Ishiguro K., Yamaki M., Takagi S., Ikeda Y., Kawakami K., Ito K., Nose T., J. Pharmacobio-Dyn., 11, 131-136 (1988).

24) Ishiguro K., Yamaki M., Takagi S., J. Nat. Prod., 46, 532-536 (1983).

25) Chang I. M., Phytother. Res., 11, 189-192 (1997).

26) Chang I. M., Emerging Drugs, 1, 109-124 (2001).

27) Touyama R., Takeda Y., Inoue K., Kawamura I., Yatsuzuka M., Ikumoto T., Shingu T., Yokoi T., Inouye H., Chem. Pharm. Bull., 42, $668-673$ (1994).

28) Touyama R., Inoue K., Takeda Y., Yatsuzuka M., Ikumoto T., Moritome N., Shingu T., Yokoi T., Inouye H., Chem. Pharm. Bull., 42, $1571-1578$ (1994).

29) Moritome N., Kishi Y., Fujii S., J. Sci. Food Agric., 79, 810-814 (1999).

30) Imazawa T., Nishikawa A., Furukawa F., Kasahara K., Ikeda T., Takahashi M., Hirose M., Food Chem. Toxicol., 38, 313-318 (2000).

31) Zhao W., Ji X., Ye Q., Qin G., Xu R., Zhu X., Tianran Chanwu Yanjiu Yu Kaifa, 12, 41-44 (2000). CAS: 63 (Pharmaceuticals).

32) Bartholomaeus A., Ahokas J., Toxicol. Lett., 80, 75-83 (1995).

33) Sung H. W., Huang R. N., Huang L. L. H., Tsai C. C., Chiu C. T., J. Biomed. Mater. Res., 42, 560-567 (1998).

34) Konno K., Hirayama C., Yasui H., Nakamura M., Proc. Natl. Acad. Sci. U.S.A., 96, 9159-9164 (1999).

35) Kim D. H., Kim B. R., Kim J. Y., Jeong Y. C., Toxicol. Lett., 114, 181-188 (2000). 